Review

\title{
Tools for Assessing the Impacts of Climate Variability and Change on Wildfire Regimes in Forests
}

\author{
Hety Herawati ${ }^{1, *}$, José Ramón González-Olabarria ${ }^{2}$, Arief Wijaya ${ }^{\mathbf{1}}$, Christopher Martius ${ }^{\mathbf{1}}$, \\ Herry Purnomo ${ }^{1,3}$ and Rubeta Andriani ${ }^{1}$
}

1 Center for International Forestry Research (CIFOR), Jalan CIFOR, Situ Gede, Bogor Barat 16115, Indonesia; E-Mails: a.wijaya@cgiar.org (A.W.); c.martius@cgiar.org (C.M.); h.purnomo@cgiar.org (H.P.); rubeta312@gmail.com (R.A.)

2 Forest Sciences Centre of Catalonia (CEMFOR-CTFC), Ctra St. Llorenç de Morunys Km 2 ES-25280 Solsona, Spain; E-Mail: jr.gonzalez@ctfc.es

3 Faculty of Forestry, Bogor Agricultural University, Jalan Raya Darmaga, Bogor 16680, Indonesia

* Author to whom correspondence should be addressed; E-Mail: h.herawati@cgiar.org; Tel.: +62-251-8622622; Fax: +62-251-8622100.

Academic Editor: Jianbang Gan

Received: 24 February 2015 / Accepted: 23 April 2015 / Published: 30 April 2015

\begin{abstract}
Fire is an intrinsic element of many forest ecosystems; it shapes their ecological processes, determines species composition and influences landscape structure. However, wildfires may: have undesirable effects on biodiversity and vegetation coverage; produce carbon emissions to the atmosphere; release smoke affecting human health; and cause loss of lives and property. There have been increasing concerns about the potential impacts of climate variability and change on forest fires. Climate change can alter factors that influence the occurrence of fire ignitions, fuel availability and fuel flammability. This review paper aims to identify tools and methods used for gathering information about the impacts of climate variability and change on forest fires, forest fuels and the probability of fires. Tools to assess the impacts of climate variability and change on forest fires include: remote sensing, dynamic global vegetation and landscape models, integrated fire-vegetation models, fire danger rating systems, empirical models and fire behavior models. This review outlines each tool in terms of its characteristics, spatial and temporal resolution, limitations and applicability of the results. To enhance and improve tool performance, each must be continuously tested in all types of forest ecosystems.
\end{abstract}


Keywords: climate change; climate variability; forest fire; tool

\section{Introduction}

Fire is an important driver of ecological processes in many forests and determines their species composition and landscape structure [1]. Wildfires are natural processes in many forest ecosystems, but they can have undesired on-site effects [2], such as degradation of vegetation, impacts on biodiversity, loss of lives and property, and off-site effects, such as smoke, impacts on human health and carbon emissions to the global atmosphere. These undesired impacts may intensify because fire activity is projected to increase for many regions of the world under the current change in climate [3-7].

According to the Intergovernmental Panel on Climate Change (IPCC) fifth assessment report (AR5) [8], there is strong evidence of warming atmosphere and temperatures that can affect extreme events. At the end of the twenty-first century (2081-2100), the global mean surface temperature may be higher by approximately $1{ }^{\circ} \mathrm{C}-3.7^{\circ} \mathrm{C}$, the intensity and/or duration of droughts on regional to global scales are likely to increase, and tropical cyclone activity (e.g., in the Western North Pacific) may increase compared to 1986-2005 [8]. Subsequently, climate change may induce global variations in potential fire hazard [5,9], causing an increase in the probability of fire occurrence [4,7], due to more and larger fires projected under climate change scenarios $[10,11]$.

Defining the occurrence, extent and impact of forest fires requires knowledge about different factors influencing the initiation, spread and impact of forest fires, together with an assessment of the vulnerability of the resources affected by fire. Fires will start and spread when there are ignition sources, fuel availability and favorable flammability conditions (Figure 1). Fires may be ignited anthropogenically or naturally, the relative importance of each of the ignition causes is specific to the region of study and are influenced by social and environmental factors $[12,13]$ Once an ignition occurs, fires may spread if fuels are available and flammability conditions are conducive. The influence of forest fuels both dead and alive on fire behavior depends on their quantity, continuity and condition [14]. The capacity of the fuels to sustain combustion (flammability) depends on the fuel characteristics, such as fuel moisture content and chemical composition. The chemical composition of the forest fuels is directly related to the floristic composition of the forest [15], whereas the moisture content depends both on the type of fuels (e.g., size, dead/alive, biophysical structure) and the climatic conditions present before the fire occurred [16]. Although climate is the main determinant in large-scale variations of fuel flammability [11], other factors that control the build-up of dead fuels include stand age, stability and health as well as interactions with other disturbances (e.g., pests, diseases) $[17,18]$. The natural development of a forest defines the availability of forest fuels; human activity, through forest management, can modify the species composition and structure of the living fuels, playing an important role in explaining the behavior of fires and their effect on the remaining vegetation $[19,20]$. 


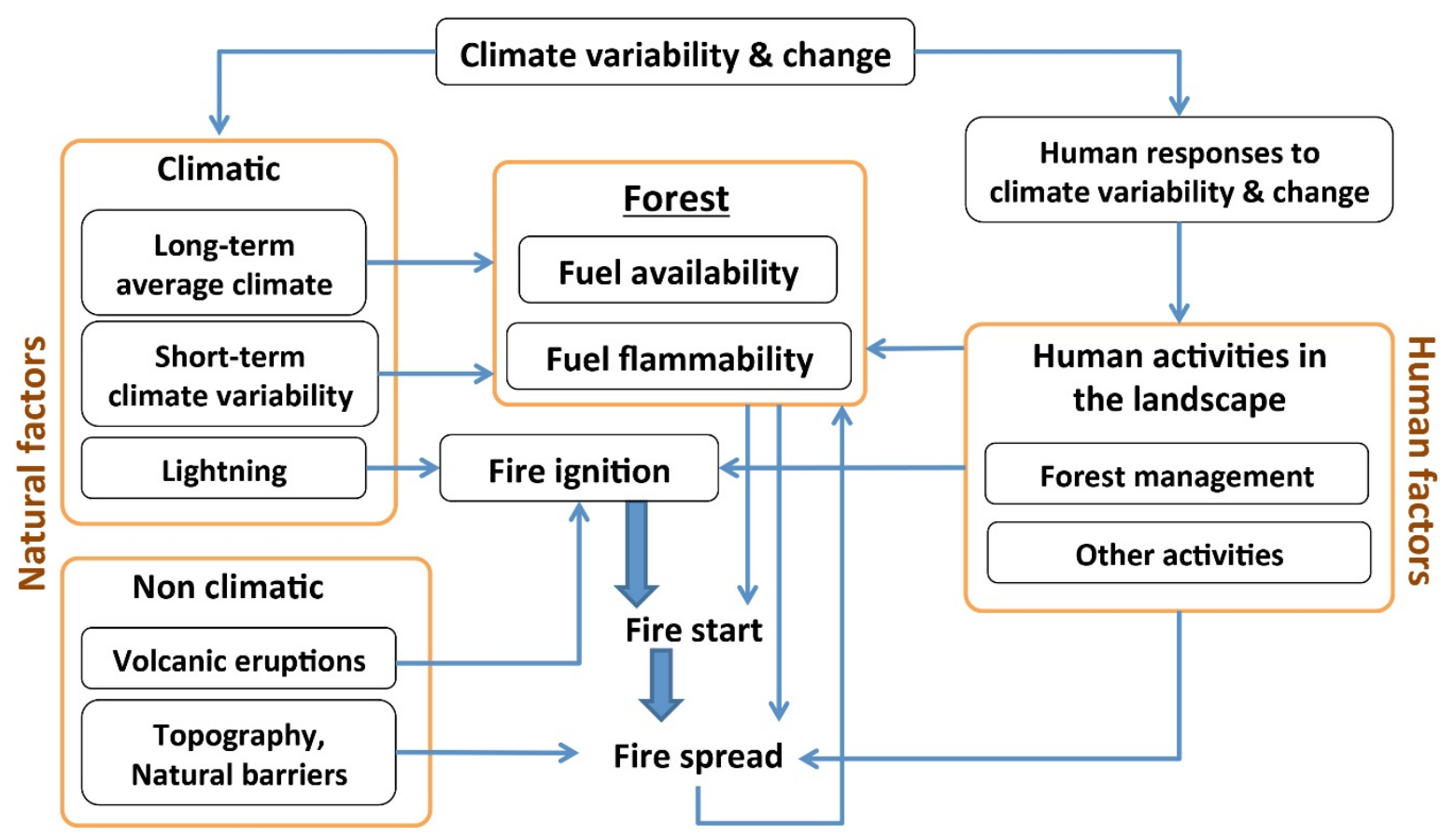

Figure 1. Fire factors and possible impacts of climate variability and change on forest fires.

The recent and future change in climate is expected to modify several factors influencing the occurrence of ignitions, fuel availability and flammability (Figure 1). Climate change for example may alter the regime of storms, and so directly modify the number of lightning-caused fires [21] and indirectly modify the number of human-caused fires [22]. Climate change may also lead to shifts in the floristic composition and structure of forests [4,23]. Furthermore, changing climate may modify short-term climate variability, leading to higher temperatures, lower humidity and stronger winds, which may be undesirable in some cases. These conditions may increase fuel flammability and fire spread [21,24].

Addressing the impact of climate change on forest fires is not an easy task and can be tackled in multiple ways, depending on the specific objectives of the study, the temporal and spatial framework, the available data, and the modeling approach. This paper will identify and describe tools that can be used to assess the impacts of climate variability and change on forests, fuels and forest fires.

We reviewed the literature, reports and gray/white papers on tools and methods used to assess or calculate the current activity of forest fires and fire hazard. The review included systems used for predicting the future evolution of forest fuels, models to assess factors influencing the probability of fire occurrence, models generating scenarios regarding the combined evolution of forests and fires, and models simulating the behavior of fire under current or future climate conditions. We obtained this literature from several sources. We searched for articles using Web of Knowledge/Science (http://apps.webofknowledge.com, published in 2000-2013) using keywords of "Topic = (climat* AND chang*) AND Topic $=($ forest* AND fire* OR wildfire*)". We also obtained articles from Google Scholar (http://scholar.google.com) search engine, libraries' and authors' collections. 


\section{Remote Sensing Approaches: Monitoring and Mapping Fires and Fuel Characteristics}

Remote sensing data and methods can model the possible impacts of climate variability, changes in forest fire regimes and provide the required information on early warning systems. Information from remote sensing can be used to assess fuel characteristics, define historic fire regimes, measure potential fire hazards and monitor active fires. Fuel flammability, availability and types are crucial factors determining the possibility of fuel ignition and potential fire behavior, including the speed of fire spread. By providing information about fire regimes over large areas and the current status of vegetation, remote-sensing tools can generate baseline information on the impact of fires and provide information on the current fire hazard that can be used to generate scenarios under climate change. Remote sensing data can be used as inputs to other tools such as empirical ignition models and fire behavior models to study the potential fire behavior and fire occurrence probability [25].

Remote-sensing technologies provide information about fire at different spatial and temporal scales. For example, mapping active fires requires monitoring systems that can capture data on fire events at near real time so that satellite data with daily revisit time but less than $250 \mathrm{~m}$ resolution is often used. In contrast, monitoring burned scar areas needs data at higher spatial resolution (i.e., 15-30 m resolution) to differentiate burned areas from other land cover types, but may not require data on daily basis. Satellite sensors with moderate temporal resolution (i.e., 16-30 days resolution) are useful to characterize medium to large sized burned areas.

Several satellites and aerial sensors are available for monitoring active fires, burned areas, fuel availability and fuel flammability (Table 1). Most of the approaches rely on satellites, which integrate multispectral sensors (ASTER, AVIRIS, Ikonos, Landsat, MASTER, MODIS, NOAA-AVHRR, RapidEye). Sensors that incorporate infrared and near-infrared bands can identify vegetation presence, changes or stress status, and heat release from active fires. Another approach is to fuse synthetic aperture radar (SAR) and laser scanning data (LIDAR). These provide interesting features as they can disregard clouds or vegetation when measuring soil moisture (SAR), or generate a three-dimensional image of the vegetation/fuel distribution (LIDAR).

The National Oceanic and Atmospheric Administration-Advanced Very High Resolution Radiometer (NOAA-AVHRR) has a coarse spatial resolution of $1 \mathrm{~km}$ but has high temporal resolution (1 day). It provides a good platform for detecting active wildfires and mapping burned scars and has been used in different biomes [26-29]. It also has important features for producing daily information on the normalized difference vegetation index (NDVI) [30], which can be used to map forest vegetation, identify changes in the distribution of land uses and provide information about the vigor and water stress of vegetation. Such daily vegetation indices can be applied to estimate changes in vegetation, fuel moisture and subsequently be adapted for fuel availability and flammability assessment. There are at least two NOAA polar-orbiting satellite platforms bearing AVHRR sensors, but omission/commission errors of active fire detection may still occur as a result of atmospheric and diurnal conditions that are not always optimal for data retrieval. 
Table 1. Examples and description of current remote sensing applications and their capabilities for monitoring and/or mapping active forest fires, burned areas, fuel availability, fuel flammability (marked with a $\sqrt{ }$ whenever the tool was found suitable for each specific purpose).

\begin{tabular}{|c|c|c|c|c|c|c|c|c|c|c|}
\hline \multirow[b]{2}{*}{ Sensor } & \multirow{2}{*}{$\begin{array}{c}\text { Spatial } \\
\text { Resolution }\end{array}$} & \multirow{2}{*}{$\begin{array}{l}\text { Temporal } \\
\text { Resolution }\end{array}$} & \multirow[b]{2}{*}{ Study Area } & \multicolumn{4}{|c|}{ Analyzing, Monitoring and/or Mapping } & \multirow[b]{2}{*}{ Product Features } & \multirow[b]{2}{*}{ Area Coverage } & \multirow[b]{2}{*}{ Sources/Reference } \\
\hline & & & & $\begin{array}{c}\text { Active } \\
\text { Fires }\end{array}$ & $\begin{array}{c}\text { Burned } \\
\text { Areas }\end{array}$ & $\begin{array}{c}\text { Fuel } \\
\text { Availability }\end{array}$ & $\begin{array}{c}\text { Fuel } \\
\text { Flammability }\end{array}$ & & & \\
\hline NOAA-AVHRR & $1000 \mathrm{~m}$ & 1 day & $\begin{array}{c}\text { Australia, Brazil, Central } \\
\text { Africa, Indonesia, } \\
\text { Mediterranean, North } \\
\text { America, North and South } \\
\text { Korea, Russia } \\
\end{array}$ & $\sqrt{ }$ & $\sqrt{ }$ & $\sqrt{ }$ & $\sqrt{ }$ & $\begin{array}{l}\text { Multispectral optical data, } 6 \text { bands. } \\
\text { Red and near-infrared bands (NDVI) }\end{array}$ & Large & [26-29,31-39] \\
\hline RapidEye & $5 \mathrm{~m}$ & 1 day & Germany, Indonesia, USA & & $\sqrt{ }$ & $\sqrt{ }$ & $\sqrt{ }$ & $\begin{array}{l}\text { Multispectral optical data, } 5 \text { bands } \\
\qquad(400-850 \mathrm{~nm})\end{array}$ & Small & {$[40-43]$} \\
\hline AVIRIS & $15-20 \mathrm{~m}$ & User defined & USA & & & $\sqrt{ }$ & $\sqrt{ }$ & $\begin{array}{l}\text { Hyperspectral optical data, } 220 \\
\text { bands. Visible, near-infrared to } \\
\text { shortwave infrared spectral band }\end{array}$ & Small to medium & {$[37,39,44,45]$} \\
\hline $\begin{array}{l}\text { Landsat } \\
\text { TM/ETM }\end{array}$ & $15-60 \mathrm{~m}$ & 16 days & $\begin{array}{c}\text { Brazil, France, Greece, } \\
\text { Indonesia, Portugal, } \\
\text { Spain, USA } \\
\end{array}$ & $\sqrt{ }$ & $\sqrt{ }$ & $\sqrt{ }$ & $\sqrt{ }$ & $\begin{array}{c}\text { Multispectral optical data, } \\
7 \text { bands. Red and near-infrared } \\
\text { bands, thermal band }\end{array}$ & Small to medium & {$[26,37,39,46-52]$} \\
\hline MODIS & $250-1000 \mathrm{~m}$ & $1-2$ days & $\begin{array}{c}\text { Africa, Australia, Brazil, } \\
\text { Canada, Indonesia, Russia, } \\
\text { Spain, USA }\end{array}$ & $\sqrt{ }$ & $\sqrt{ }$ & $\sqrt{ }$ & $\sqrt{ }$ & $\begin{array}{l}\text { Multispectral optical data, } 36 \text { bands. } \\
\text { Availability of active fire and burned } \\
\text { areas products }\end{array}$ & Medium to large & {$[37,39,50,53-62]$} \\
\hline BIRD & $370 \mathrm{~m}$ & User defined & $\begin{array}{l}\text { Australia, Benin, China, } \\
\text { India, Indonesia }\end{array}$ & $\sqrt{ }$ & & & & $\begin{array}{l}\text { Mid-infrared band }(\mathrm{MIR})=3.4-4.2 \\
\mu \mathrm{m} \text {; Visible and infrared sensor } \\
(\mathrm{VIS})=0.60-0.67 \mu \mathrm{m} ; \text { thermal } \\
\text { infrared band }(\mathrm{TIR})=8.5-9.3 \mu \mathrm{m} \text {; } \\
\quad \text { near-infrared band } \\
(\mathrm{NIR})=0.84-0.90 \mu \mathrm{m}\end{array}$ & Small to medium & {$[52,56,63,64]$} \\
\hline
\end{tabular}


Table 1. Cont.

\begin{tabular}{|c|c|c|c|c|c|c|c|c|c|c|}
\hline \multirow[b]{2}{*}{ Sensor } & \multirow[b]{2}{*}{$\begin{array}{c}\text { Spatial } \\
\text { Resolution }\end{array}$} & \multirow[b]{2}{*}{$\begin{array}{l}\text { Temporal } \\
\text { Resolution }\end{array}$} & \multirow[b]{2}{*}{ Study Area } & \multicolumn{4}{|c|}{ Analyzing, Monitoring and/or Mapping } & \multirow[b]{2}{*}{ Product Features } & \multirow[b]{2}{*}{ Area Coverage } & \multirow[b]{2}{*}{ Sources/Reference } \\
\hline & & & & $\begin{array}{l}\text { Active } \\
\text { Fires }\end{array}$ & $\begin{array}{c}\text { Burned } \\
\text { Areas }\end{array}$ & $\begin{array}{c}\text { Fuel } \\
\text { Availability }\end{array}$ & $\begin{array}{c}\text { Fuel } \\
\text { Flammability }\end{array}$ & & & \\
\hline ASTER & $15-90 \mathrm{~m}$ & 4-16 days & $\begin{array}{l}\text { Brazil, Greece, Southern } \\
\text { Africa, USA }\end{array}$ & $\sqrt{ }$ & & $\sqrt{ }$ & $\sqrt{ }$ & $\begin{array}{l}\text { Multispectral optical data, } 14 \text { bands. } \\
\text { Visible and near-infrared, shortwave } \\
\text { infrared, thermal infrared }\end{array}$ & Small to medium & {$[39,54,61,65-67]$} \\
\hline MASTER & $5-50 \mathrm{~m}$ & User defined & USA & & $\sqrt{ }$ & $\sqrt{ }$ & $\sqrt{ }$ & $\begin{array}{c}50 \text { bands }(0.4-13 \mu \mathrm{m}),(\text { Visible and } \\
\text { near-infrared (VNIR), shortwave } \\
\text { infrared (SWIR), mid-infrared } \\
\text { (MIR) and thermal infrared (TIR)) }\end{array}$ & Small to medium & {$[68,69]$} \\
\hline Ikonos & $1 \mathrm{~m}$ & $\begin{array}{l}3-5 \text { days } \\
\text { (off nadir) }\end{array}$ & Greece & & $\sqrt{ }$ & $\sqrt{ }$ & $\sqrt{ }$ & Multispectral optical data & Small & [70] \\
\hline ERS SAR & $25 \mathrm{~m}$ & 35 days & $\begin{array}{l}\text { Canada, France, Greece, } \\
\text { Indonesia, Spain, USA }\end{array}$ & & $\sqrt{ }$ & $\sqrt{ }$ & $\sqrt{ }$ & Synthetic aperture radar & Small to medium & {$[33,46,71-75]$} \\
\hline Airborne LIDAR & $0.5 \mathrm{~m}$ & User defined & $\begin{array}{l}\text { Germany, Indonesia, } \\
\text { Portugal, Spain, USA }\end{array}$ & & & $\sqrt{ }$ & $\sqrt{ }$ & $\begin{array}{l}\text { Laser scanner, capability to be } \\
\text { integrated for modeling fire behavior }\end{array}$ & Small & {$[25,76-82]$} \\
\hline
\end{tabular}


RapidEye is a multispectral system that uses five satellites to collect 4 million $\mathrm{km}^{2}$ of data per day with high spatial resolutions $(5 \mathrm{~m})$ [83]. The instrument is suitable to map fuel availability by monitoring forest fragmentation [40], changes in vegetation cover or land uses [42], and fuel flammability by detecting forests under stress [41]. The primary disadvantage of any spectral sensor is that it cannot penetrate cloud cover [40].

The Airborne Visible InfraRed Imaging Spectrometer (AVIRIS) provides high spatial resolution data (15-20 m) using spectral bands from visible and near infrared to shortwave infrared. It has been used in the US to analyze fuel availability and fuel flammability [37,44].

Landsat data is widely applied for multiple purposes, ranging from vegetation, biomass, fuel and burned area mapping [33,36,37]. This sensor has multispectral bands (i.e., from visible green to near infrared bands), thermal bands and one panchromatic band. The most recent Landsat 8 or Landsat Data Continuity Mission (LDCM) has similar capabilities to previous Landsat generations, but includes additional bands to characterize aerosols and cirrus cloud combinations [84].

Moderate Resolution Imaging Spectroradiometer (MODIS) provides multispectral imagery at mid-range spatial resolutions $(250-1000 \mathrm{~m})$ that incorporates an 'active fire product' and 'burned area product' providing information on burning fires locations and the extent of burn scars on a daily basis. With a temporal resolution of one to two days, MODIS data are widely used for near-real-time monitoring of active fires and analyzing burned areas in the tropics and subtropics [50,53,55-57,59,61,62]. One interesting feature of MODIS active fires product is that it provides information on image quality and how it influences the possible misclassification of fire events.

Bispectral and Infrared Remote Detection (BIRD) is a German Aerospace Center (DLR) satellite mission that was designed to support the detection of active fires and volcanoes through the capture and analysis of emitted infrared radiation. This satellite is used to calibrate MODIS sensors as BIRD has higher spatial resolution $(370 \mathrm{~m})$ and better capability to detect smaller and less intense fires than MODIS. Nevertheless, BIRD only collected satellite imagery of selected ESA project FUEGOSAT target areas during 2001-2004, e.g., in Australia, China, India and Indonesia [64].

The Advanced Spaceborne Thermal Emission and Reflection Radiometer (ASTER) is an optical sensor similar to MODIS and Landsat but it collects data at a higher spatial resolution of $15 \mathrm{~m}$ and has 16 days of revisit time. ASTER visible and near infrared bands can characterize active fires, map forest fuels/fuel availability and assess fuel flammability. Similar to MODIS and Landsat Thematic Mapper/Enhanced Thematic Mapper (TM/ETM), ASTER has been used for detecting fires in different ecosystems, and for the characterization and mapping of vegetation/fuels [54,61,65].

The MODIS/ASTER Airborne Simulator (MASTER) collects data sets that have higher spatial resolution $(5-50 \mathrm{~m})$ than the spaceborne data sets [69]. The instrument can capture images from different altitudes. The sensor has good spectral and spatial resolution, but it is expensive for regional fire severity mapping [68]. The image is processed using a radiative transfer model (MODTRAN). The instrument has been used in the US to analyze burned areas, fuel availability and flammability $[68,69]$.

Ikonos is an example of a satellite with a high spatial resolution, at $1 \mathrm{~m}$. It is used in Greece [70] to assess fire affected areas, fuel availability and flammability.

Similar to thermal spectroscopic sensors, Synthetic Aperture Radar (SAR) can penetrate cloud cover so it is useful for detecting changes in vegetation cover and obtaining information on soil moisture and 
vegetation dryness through haze $[33,46,71,72]$. The ALOS Phased Array type L-band Synthetic Aperture Radar (PALSAR) and the European Remote Sensing (ERS) SAR are examples of SAR.

Airborne Light Detection And Ranging (LIDAR) is an instrument that provides three-dimensional information on the arrangement of a number of features, including vegetation and fuel distribution. Information from airborne LIDAR can be used to produce fuel maps/availability, which can be incorporated into fire behavior models. The LIDAR technique is used to model surface fuels $[25,77,78,81]$, measure canopy related variables needed for predicting crown fire activity [76] and measure aboveground biomass at fine spatial resolution $(0.5 \mathrm{~m})[79]$.

Based on the previously mentioned remote sensing instruments, several initiatives have been established to develop global burned area data sets. Examples of these initiatives and their status are given in Table 2. The table illustrates an overview of global burned area products developed from 1982 to the present by different sensors and algorithms. The data sets have a range of spatial and temporal resolutions. They are useful in assessing and monitoring historic and current fires, and estimating fuel load/availability when coupled with global land cover and vegetation models.

Table 2. Global forest fire initiatives developed from remote sensing tools.

\begin{tabular}{|c|c|c|c|c|c|}
\hline Data Set & Time Span & Satellite & $\begin{array}{c}\text { Spatial } \\
\text { Resolution }\end{array}$ & $\begin{array}{l}\text { Temporal } \\
\text { Resolution } \\
\end{array}$ & Status \\
\hline GFED3 & 1996-present & MODIS, TRMM/VIRS, ATSR & $0.5^{\circ} \times 0.5^{\circ}$ & Monthly & Operational \\
\hline MCD45A1 & 2000-2009 & MODIS & $500 \mathrm{~m}$ & Monthly & Operational \\
\hline L3JRC & $2000-2007$ & SPOT VEGETATION & $1 \mathrm{~km}$ & Daily & Finished \\
\hline GBA2000 & 2000 & SPOT VEGETATION & $1 \mathrm{~km}$ & Monthly & Finished \\
\hline GLOBCARBON & $1998-2007$ & $\begin{array}{c}\text { SPOT VEGETATION, } \\
\text { ATSR-2, AATSR }\end{array}$ & $1 \mathrm{~km}$ & Monthly & Finished \\
\hline GBS & 1982-1999 & NOAA-AVHRR GAC & $8 \mathrm{~km}$ & Weekly & Finished \\
\hline GLOBSCAR & $>2000$ & ERS2-ATSR2 & $1 \mathrm{~km}$ & Monthly & Finished \\
\hline
\end{tabular}

Modified from Mouillot et al. 2014 [85]. Note: GFED3=Global Fire Emissions Database; MODIS=Moderate Resolution Imaging Spectroradiometer; TRMM=Tropical Rainfall Measuring Mission; VIRS=Visible and Infrared Scanner; MCD45A1=MODIS Burned Area Product; ATSR=A Long-Track Scanner Radiometer; GBA=Global Burned Area; SPOT=Satellite Pour l'Observation de la Terre (Satellite for observation of Earth); L3JRC=SPOT Burned Area Product; AATSR=Advanced ATSR; GBS=Global Burnt Surface; NOAA-AVHRR=National Oceanic and Atmospheric Administration-Advanced Very High-Resolution Radiometers; GLOBSCAR=ATSR World Burned Surface Atlas.

\section{Dynamic Global Vegetation and Landscape Models}

Dynamic global vegetation and landscape models can assess the effect of climate variability and change on fire regimes through vegetation evolution assessment. They simulate vegetation (fuel/fire hazard) dynamics at different spatial scales. These models calculate long-term and large-scale predictions of vegetation evolution under changing conditions. They consider disturbances as one of the main drivers of vegetation dynamics and changes in landscape configuration. Vegetation simulation models include The Lund-Potsdam-Jena Dynamic Global Vegetation Model (LPJ-DGVM) [86], LANDIS II [87], LANDCLIM [88,89], HyLand [90], the Hybrid DGVM [90], ORCHIDEE [90], Sheffield DGVM [90], TRIFFID [90] and CACTOS [91], but here we focus on two that have been used 
to assess how fire activity evolves with respect to climate, vegetation dynamics, and landscape pattern. These two models are described below.

The Lund-Potsdam-Jena Dynamic Global Vegetation Model (LPJ-DGVM) combines process-based, land-atmosphere carbon and water exchanges and terrestrial vegetation dynamics [92]. The model is useful in showing multiple aspects of biospheric vulnerability to climate and land-use change and the feedback from land surface change [86]. This tool has been run with the HADCM2 historical and future climate simulation to predict impacts of climate change on historical and future (up to 2100) global vegetation carbon sequestration and fuel availability $[90,93]$. The model predicts a positive cumulative net carbon uptake by 2099; the peak annual carbon uptake will take place in the mid-2050s and then drop thereafter [90].

LANDIS II and LANDCLIM simulate forest succession, disturbances, forest management, climate change and seed dispersal across large landscapes for long periods of time, with a relative fine spatial resolution of $25 \mathrm{~m}$. LANDIS II is essentially tailored for data and knowledge from the US, but it has been implemented in other areas such as northeastern China [87]. LANDCLIM has been tested and adapted to the European Alps, the American Rocky Mountains [88,89], and the Mediterranean ecosystem [94]. LANDCLIM has been used for assessing the effect of climate change and fires on the vegetation dynamics of the European Alps for the period 2071-2100 using the A2 scenario and the CHRM regional climate model, while evaluating future fire danger in the region [88]. The model predicts that climate change will affect forest vegetation significantly, especially in terms of biomass distribution and species composition along altitudinal gradients.

\section{Modeling Fuel Characteristics and Fire: Integrated Fire-Vegetation Models}

Integrated fire-vegetation models (IFVMs) can also be used to study how fire activity may change in the future. DGVMs and IFVMs differ in terms of their focus. IFVMs integrate fire and vegetation models and study the combined effect of changing conditions on vegetation dynamics and fire regime, and their interactions. DGVMs study the impact of fire and other disturbances on vegetation dynamics, including how they shape future landscapes. The limitations of IFVMs come from their often large-scale assessments that require generalized inputs. IFVMs and DGVMs study the effect of climate variability/change and other factors on fuel availability and fire regime and analyze their interactions. IFVMs for example can predict fire occurrence. Some examples of IFVMs used to predict fire activity include:

The Global FIRe Model (GlobFIRM) can simulate fires to occur globally or in a fraction of the study area, depending on the probability of fire occurrence as a function of daily soil and fuel moisture, and the length of the fire season. GlobFIRM results have been assessed against historical area burned. The Glob-FIRM, fire module in the LPJ-DGVM for example, has been used to analyze the role of long-term historical (1901-1998) climate change and vegetation in global fire regimes in North, Central and South America, boreal Eurasia, the Mediterranean and Africa [86]. Compared to historical area burned, GlobFIRM successfully simulates fire regimes in some of these study areas [86]. A regionalized version of the model (Reg-FIRM) has been used in Germany [95] under changing climate conditions until 2100 using the A1FI emission scenario [96] to predict long-term future vegetation and fire regime variations [95]. 
The Large-fire Simulator (FSim) system is another potential tool for assessing the impact of climate variability and change on wildfire. It has been used in the US for simulating short-term historical risk of large-fire occurrence by incorporating factors such as fuel, topography and climate (e.g., temperature, precipitation, air humidity and wind) [97]. Because FSim can simulate fire occurrence and growth for thousands of years [97], it can simulate full fire regimes, considering variables such as fire occurrence, location, size and distribution of multiple fires [98].

$\mathrm{MC1}$ is a dynamic vegetation model that can assess climate change impacts on ecosystem structure and function. It combines physiologically based biogeographic, biogeochemical processes and a fire disturbance model [92,99]. It has an MCFIRE fire module that mechanistically simulates the occurrence and impacts of fire events using thresholds of drought and the rate of fire spread. Fuel moisture, fuel loading and fuel type are calculated from input climate data and vegetation simulation models within MC1. With a spatial resolution of $150 \mathrm{~m}, \mathrm{MC} 1$ is suitable for landscape to global scales applications [99,100]. It has been applied to assess the effects of fire, grazing and climate in South Dakota, USA [99], the effects of climate on wildfire and carbon dynamics in the Pacific Northwest, USA [101], and the impacts of global vegetation shifts on fire under different climate projections [102].

\section{Modeling Dynamics of Fuel Flammability: Fire Danger Rating Systems}

Fire Danger Rating Systems (FDRSs) are used to assess fuel and weather conditions and provide estimates of fuel flammability and potential fire behavior. They can provide daily reports and maps on fire danger for short-term forecasts under current climatic conditions, but they are also used to assess climate change impacts on long-term future wildfire hazards. FDRSs have been used in many parts of the world for more than 40 years. Some of the most popular FDRSs are the Canadian Forest Fire Danger Rating System (FFDRS) [103], the Australian Forest Fire Danger Rating/McArthur Forest Fire Danger Index (FFDI) [104], the United States National Fire Danger Rating System (NFDRS) [105], the Keetch-Byram Drought Index (KBDI) [106], the Nesterov Index [105] and the Zhdanko Index [106]. They have been applied in many countries, for example, the Canadian FFDRS has been used to forecast impacts of climate change on future fire hazard in many parts of the world, including Canada [107-110], North America [111], Portugal [112], the Iberian Peninsula and North Africa [103]. The McArthur FFDI has been used to predict future impacts of climate change on fire hazard in Australia in a 30 year time horizon [104]. And the US NFDRS has been implemented in the United States to predict climate change influence on fire hazard from 1950 to 2099 [113].

The KBDI has been used in global analyses to determine future fire activity under climate change. Two assessments of global future wildfire potential under climate change using KBDI show that, due to climate change, the wildfire potential for the period 2070-2100 may increase in places such as the United States, South America, Central Asia, Southern Europe, Southern Africa and Australia [5,114]. A modified version of KBDI has also been tested to predict climate change impacts on fire hazards in the eastern part of Kalimantan and eastern part of Sumatra, Indonesia [115]. The results show that fire hazards in these sites may significantly increase in 2070-2100 (drought index $=825-960$ ) compared to 1960-1990 (drought index $=460-544$ ).

Some FDRSs have been coupled with climatology databases to assess fire danger. For example, in Northern Eurasia the KBDI, Nesterov, and Zhdanko indices were coupled with the Global Daily 
Climatology Network and Global Synoptic Climatology Network to assess fire danger over the past 50 years across FDRSs [114]. The results indicate that there have been no significant changes in potential forest fire danger in this region during the past 50 years [114]. Climate data can be integrated into FDRSs and remote sensing fire products can be used to assess how well predicted fire danger corresponds to actual fire activity. For example, the Nesterov Index combined with MODIS MCD45 burned area product and the Vegetation Continuous Fields product have also been implemented in Africa to model burned areas. The simulation for the period 1980-2060 predicts a considerably decreasing trend of burned area [116].

FDRSs have been used to project fire danger into the future, but they often work on coarse resolution scales and their output metrics are usually dependent on climate conditions. NDFRS, for example, works on a resolution of $4 \mathrm{~km}$ [117], FFDRS on $10 \mathrm{~km}$ [118] and the KBDI on $50 \mathrm{~km}$ [115]). Because FDRSs rely so heavily on climate input, and other factors can define fire activity, projections using FDRSs provide limited information.

\section{Modeling Fire Ignition and Occurrence: Empirical Models}

Empirical models are useful for analyzing and predicting the impacts of climate variability (and non-climatic factors) on fire probability, fire occurrence and fire frequency. These models have been used to predict both short-term (less than 30 years) historical, and short-term and long-term (30 or more years) future forest fire probability. Different approaches have been used for ignition/fire occurrence modeling. Most of them have been implemented at a single spatial scale, either fine-scale being based on the proximity to hazardous elements [119-122] or broad-scale, based on the aggregation of both fire ignition events and influencing factors at an administrative or ecological level [22,123-125]. However, fire ignitions/occurrences can be modeled using different spatial scales, according to the available factors and data.

Empirical models require supporting data on climate, demography, accessibility, land-cover types, geography, remote sensing, fire danger, and fire history. The climate data used in the models can be derived from observed weather data (e.g., temperature, relative humidity, precipitation, wind) or from climate models. Demographic data for the models include population density and information about human activities. Accessibility information includes distance to roads, paths, railways, rivers or settlements. Examples of land-cover data are agriculture land, grassland, height and structure of vegetation. Geographic data include site location, slope and elevation information.

Often, many of these supporting data for investigating fire danger come from remote sensing products such as: Active fire data from MODIS, burn scar map from MODIS, Landsat or NOAA-AVHRR and vegetation height and structure, and canopy cover map from LIDAR, Fire Danger Rating Indices from Keetch-Byram Drought, Canadian Fire Weather, Palmer Drought Severity and Fosberg Fire Weather Indices.

There are many kinds of statistical methods used to analyze historical fire records and predict the probability of fire occurrence. Logistic regression has been one of the most common methods used to analyze or predict the impacts of climate variability (and non-climatic factors) on fire occurrence. It has been used to predict short-term history of wildfire dynamics in Greece (1970-1995) and wildfire probabilities in the United States (1985-1995 [12] and 1998-2003 [126]). It also has been used to 
analyze the role of climate change and non-climatic factors on the long term historical (1950-1992) wildfire probability on Vancouver Island, Canada [120], predict the short term future of large fire events (1 month) and fire probability (1 year) in Mesoamerica [127], and predict the impacts of climate change (and non-climatic factors) on the long-term future (2070-2099) fire risks and hazard in the USA [128].

Neural networks have been implemented in Spain to analyze the impacts of climate variability (and non-climatic factors) on the short-term historical (1988-2001) forest fire risk [129] and in Canada to predict the short-term historical (1986-1990) fire risk and hazard [122]. Multiple regressions, decision trees, Random Forest, neural network and support vector machines were used in Portugal to analyze burned areas using historical, short-term (2000-2003) climate variability [130].

The tools have also been used for analyzing impacts of climate change and variability, and non-climatic factors on short term and long term historical and current fire occurrence and fire frequency. For examples Bayesian networks have been used e.g., in Swaziland to analyze the impacts of climate change and variability on short term historical fire occurrence and predict 2000-2008 fire occurrence [131]. Classification and regression trees have been used in Spain to project 1991-2002 fire occurrence [132]. Correlation analysis was used, e.g., in the USA, to analyze the 1985-2002 fire occurrences [133]. K-nearest neighbors classifier, naive Bayes, J48 decision trees, jRIP classification rules, logistic regression, support vector machines, Bayesian networks, Adaboost, bagging, Random Forest have been used, e.g., in Slovenia, for predicting short-term historical (2000-2004) fire occurrences [134]. Finally, multiple regression and tree-based models have been used to analyze the impacts of climate change and other factors on the long-term historical (1961-1990) fire frequency in the USA [135].

The abovementioned examples show that empirical models are useful to predict/analyze wildfire situations with varied temporal resolution and accuracy. Most of the tools were used to analyze historical fires. Nevertheless, the models can also be used to predict short-term future wildfires as well as long-term future fires. When modeling fire occurrence based on historic fires, we must consider that ignition occurrence has an inherent degree of uncertainty associated with it. In order to obtain meaningful results through modeling, a minimum level of spatial and temporal aggregation of fire ignitions is required, and such level of aggregation varies across regions together with human behavior; the relative importance of ignition causes also varies across regions. In addition, the minimum size of the recorded fires used for defining the dependent variable of the models varies among studies. This has an important impact on the results, as the factors that define the occurrence of fires will move from those that explain the cause of ignition (in the case of small fires in the study), to those that relate to the spread of fires (as the minimum size of fires increases). For these reasons, we must use a critical approach rather than just a numerical one and compare results from different regions and data sets.

\section{Modeling Fuel Flammability, Fire Occurrence, Spread and Effects: Fire Models}

Fire models are useful to predict fuel flammability, fire occurrence, fire behavior and fire effects under certain climate/weather conditions. These models were developed to support fire management activities including prescriptive fire, fuel hazard assessment, forest and fuel management planning and management of suppression. Examples of these systems include: RisQue (Risco de Queimada/fire 
risk model), Coupled Atmosphere-Wildland Fire-Environment (CAWFE), FireFamilyPlus, BehavePlus, FARSITE, FSPro and FlamMap.

RisQue is a simple geographic information system that uses a soil-water balance model to approximate soil moisture, which is influenced by evapotranspiration and rainfall, to relate water availability to vegetation stress, growth, forest structure and other fire-related variables such as flammability. RisQue has been used to assess the effect of climate on forest flammability in the Amazon from 1996 to 2001 [136].

Coupled Atmosphere-Wildland Fire-Environment (CAWFE) simulates fire spread and fuel consumption to assess smoke haze emission to the atmosphere and the feedback to winds characteristics and to fire behavior [137]. It combines meteorological flow, fire behavior, and fire-induced winds and it has two modules of numerical weather prediction model and fire behavior module and has been used in the US [138].

FireFamilyPlus can summarize and analyze weather observations, associate weather with local fire occurrence data, and compute fire danger indices based on the US NFDRS. By incorporating the fire occurrence record into the analysis, the software can show the historical relationships between climate/weather conditions and fire occurrence trends $[139,140]$. Although the system is not classified as an FDRS, it provides important information for active fire management from other FDRSs. FireFamilyPlus cannot only be used in active fire management, but can also provide information for fire-vegetation models such as FSim.

BehavePlus-Fire Modeling System provides information about fire behavior (rate of spread, flame length, fire line intensity or spotting distance), fire environment (fuel moisture), and fire effect (scorch height and tree mortality). BehavePlus provides simple, comprehensive graphs, tables and diagrams [141,142]. It offers a platform to understand the behavior of fire with specific fuels and weather conditions, or how fire will behave under different conditions. The tool is useful for fire investigation, wildfire behavior prediction and fuel hazard assessment activities.

FARSITE-Fire Area Simulator predicts the area growth of individual fire events and their behavior, explained in variables such as flame length and rate of spread [143]. The model requires accurate geo-referenced data on topography, vegetation and fuel attributes together with weather data to predict 2-dimensional fire growth and area burned during a short period of time (e.g., 1 day). The model predicts fire behavior in a specific location (cell) depending on the specific conditions within that cell and neighboring cells at the time of burn. The system is mainly used to recreate the growth of past fires; plan short-term fuel management across a landscape, or plan longer-term forest management, taking the evolution of the vegetation, the predicted weather and the ignitions into account; or estimate the consequences of prescribed fires. The FARSITE system is widely used for active fire management or research tasks within the US and Europe.

The FSPro-Fire Spread Probability, used in the US Wildland Fire Decision Support System [144], a system that is designed to determine the probability that a fire will spread to any given point, assuming an initial ignition or fire perimeter [141]. Using similar landscape information (such as FARSITE, FSPro) performs hundreds or thousands of separate fire growth simulations during specific simulation durations.

The FlamMap is a fire mapping and analysis system which estimates potential fire behavior across a landscape, by introducing landscape information similar to that in FARSITE (e.g., raster maps of slope, elevation, aspect, fuel type, tree height, canopy base height, canopy bulk density, canopy cover) but with 
constant values on fuel moisture and weather. The system produces fire behavior calculations such as spread rate, flame length, fire line intensity and fire crowning for each point on the studied area $[139,145]$. FlamMap can also calculate travel times for a fire, which is useful in determining effective fuel treatment locations.

With the exception of RisQue and CAWFE, these models share similar routines and sub-models; all were developed by the Missoula Fire Sciences Laboratory and the Rocky Mountain Research Station, USA. However, they differ from each other in terms of the number of fire events simulated and the way they handle results both temporally and spatially. They work at shorter temporal scales than DGVMs and IFVMs (i.e., LPJ-DGV, LANDIS II, LANDCLIM, FSim) for predicting fuel availability and often in smaller spatial scales. Additionally, their spatial resolution and accuracy are better than DGVMs and IFVMs for predicting fuel availability. The use of the abovementioned fire behavior models is often not feasible for long-term predictions but they can be used to simulate short-term future conditions (static or a few days) or provide results to adjust or validate long-term simulations of climate change effects on fire activity.

\section{Conclusions}

A number of tools are available to assess the impacts of climate variability and change on forest fire. The chosen tool should fit the objectives of the research, policy and management decisions. These tools have specific purposes, characteristics and limitations. Remote sensing, DGVMs and FDRSs are useful to analyze fire hazard, while empirical models are used to predict fire risk and frequency. The suitability of the tools for particular ecosystems (e.g., tropical or temperate forests) is also important; fire models may not be suitable for tropical humid forest as they are mainly developed for temperate or Mediterranean forest. Remote sensing and/or fire models can only provide short- to medium-term assessments of historical fire occurrence, while DGVM assessments can be used over longer time periods. Remote sensing and fire models can provide detailed fire assessments suitable for subnational scales, while DGVMs have relatively lower spatial resolution suitable for continent or global assessments.

Identification of the probability of fire events that vary across space and time are major challenges for modeling and assessing potential climate variability and change impacts on forest fire. Furthermore, the most realistic model results that capture climate-fire interactions are highly complex and are thus computationally expensive. Process-oriented models, such as DGVMs, usually have better representations than empirical models. Other challenges include the limitations of these tools in terms of considering ecosystem complexity and scale.

The abovementioned tools are useful for anticipating future climate variability and change impacts on forest fire and for mitigating climate change. They can be enhanced by continuously testing and adjusting for applications under different climate conditions and types of forest ecosystems. 


\section{Acknowledgments}

The authors would like to express their thanks to Bruno Locatelli for his valuable contributions and inputs to an earlier version of the manuscript and to AusAid-Agreement 63650 (now Australian Aid) for the financial support of this study.

\section{Author Contributions}

Hety Herawati managed the general framework and content of the paper. José Ramón González-Olabarria contributed to the general framework and content, especially to the sections on remote sensing, vegetation simulation models, fire danger rating systems, and fire models. Arief Wijaya contributed to the general framework and content of the paper, especially to the section on remote sensing. Christopher Martius contributed to the general content of the paper. Herry Purnomo contributed to the general framework of the paper. Rubeta Andriani contributed to the general content of the paper, especially to the section on remote sensing.

\section{Glossary}

FAO [9] provides a glossary of fire related terms: Fire danger $=$ a general term used to express an assessment of both fixed and variable factors of the fire environment that determine the ease of ignition, rate of spread, difficulty of control, and fire impact; fire hazard $=$ a fuel complex, defined by volume, type, condition, arrangement, and location that determines the degree both of ease of ignition and of fire suppression difficulty; fire risk = the probability of fire initiation due to the presence and activity of a causative agent; flammability = relative ease of igniting and burning of a given fuel;fuel = all combustible organic material; ignition $=$ the initiation of combustion.

\section{Conflicts of Interest}

The authors do not see any conflicts of interest. This paper represents the authors' views and does not necessarily represent the views of the Center for International Forestry Research, the Forest Sciences Centre of Catalonia, or the Faculty of Forestry at Bogor Agricultural University.

\section{References}

1. Trabaud, L. Postfire plant community dynamics in the Mediterranean basin. Ecol. Stud. 1994, 107, $1-15$.

2. Velez, R. Mediterranean forest fires: A regional perspective. Unasylva 1990, 162, 10-12.

3. Alo, C.A.; Wang, G.L. Potential future changes of the terrestrial ecosystem based on climate projections by eight general circulation models. J. Geophys. Res.-Biogeosci. 2008, 113, G01004, doi:10.1029/2007JG000528G01004.

4. Krawchuk, M.A.; Moritz, M.A.; Parisien, M.; Dorn, J.V.; Hayhoe, K. Global pyrogeography: The current and future distribution of wildfire. PloS ONE. 2009, 4, e5102.

5. Liu, Y.; Stanturf, J.; Goodrick, S. Trends in global wildfire potential in a changing climate. Forest Ecol. Manag. 2010, 259, 685-697. 
6. Moritz, M.A.; Parisien, M.-A.; Batllori, E.; Krawchuk, M.A.; Van Dorn, J.; Ganz, D.J.; Hayhoe, K. Climate change and disruptions to global fire activity. Ecosphere 2012, 3, art49.

7. Scholze, M.; Knorr, W.; Arnell, N.W.; Prentice, I.C. A climate-change risk analysis for world ecosystems. PNAS 2006, 103, 13116-13120.

8. IPCC Summary for Policymakers. In Climate Change 2013: The Physical Science Basis. Contribution of Working Group I to the Fifth Assessment Report of the Intergovernmental Panel on Climate Change; Stocker, T., Qin, D., Plattner, G., Tignor, M., Allen, S., Boschung, J., Nauels, A., Xia, Y., Bex, V., Midgley, P., Eds.; Cambridge University Press: Cambridge, UK; New York, NY, USA, 2013; p. 29.

9. FAO; GFMC. FAO wildland fire management terminology. Available online: http://www.fire. uni-freiburg.de/literature/glossary.htm (accessed on 9 February 2014).

10. Fauria, M.M.; Michaletz, S.T.; Johnson, E.A. Predicting climate change effects on wildfires requires linking processes across scales. Wiley Interdiscip. Rev. Clim. Chang. 2010, 2, 99-112.

11. Flannigan, M.D.; Krawchuk, M.A.; de-Groot, W.J.; Wotton, B.M.; Gowman, L.M. Implications of changing climate for global wildland fire. Int. J. Wildland Fire 2009, 18, 483-507.

12. Cardille, J.A.; Ventura, S.J.; Turner, M.G. Environmental and social factors influencing wildfires in the Upper Midwest, USA. Ecol. Appl. 2001, 11, 111-127.

13. Genton, M.G.; Butry, D.T.; Gumpertz, M.L.; Prestemon, J.P. Spatio-temporal analysis of wildfire ignitions in the St Johns River Water Management District, Florida. Int. J. Wildland Fire 2006, 15, 87-97.

14. Agee, J.; Skinner, C. Basic principles of forest fuel reduction treatments. For. Ecol. Manag. 2005, 211, 83-96.

15. Dimitrakopoulos, A. A statistical classification of Mediterranean species based on their flammability components. Int. J. Wildland Fire 2001, 10, 113-118.

16. Schoenberg, F.; Peng, R.; Huang, Z.; P, R. Detection of non-linearities in the dependence of burn area on fuel age and climatic variables. Int. J. Wildland Fire 2003, 12, 1-6.

17. Allen, C.D. Cross-scale interactions among forest dieback, fire, and erosion in northern New Mexico landscapes. Ecosystems 2007, 10, 797-808.

18. Woodall, C.W.; Nagel, L.M. Down woody fuel loadings dynamics of a large-scale blowdown in northern Minnesota. For. Ecol. Manag. 2007, 247, 194-199.

19. González, J.; Trasobares, A.; Palahi, M.; Pukkala, T. Predicting stand damage and tree survival in burned forests in Catalonia (North-East Spain). Ann. For. Sci. 2007, 64, 733-742.

20. Pollet, J.; Omi, P.N. Effect of thinning and prescribed burning on crown fire severity in ponderosa pine forests. Int. J. Wildland Fire 2002, 11, 1-10.

21. Goldammer, J.G.; Price, C. Potential impacts of climate change on fire regimes in the tropics based on MAGICC and a GISS GCM-derived lightning model. Clim. Chang. 1998, 39, 273-296.

22. Wotton, B.M.; Martell, D.L.; Logan, K.A. Climate change and people-caused forest fire occurrence in Ontario. Clim. Chang. 2003, 60, 275-295.

23. Pausas, J.G.; Bradstock, R.A. Fire persistence traits of plants along a productivity and disturbance gradient in mediterranean shrublands of south-east Australia. Glob. Ecol. Biogeogr. 2007, 16, 330 340 . 
24. Lavorel, S.; Flannigan, M.D.; Lambin, E.F.; Scholes, M.C. Vulnerability of land systems to fire: Interactions among humans, climate, the atmosphere, and ecosystems. Mitig. Adapt. Strateg. Glob. Chang. 2007, 12, 33-53.

25. González-Olabarria, J.R.; Rodríguez, F.; Fernández-Landa, A.; Mola-Yudego, B. Mapping fire risk in the Model Forest of Urbión (Spain) based on airborne LiDAR measurements. For. Ecol. Manag. 2012, 282, 149-156.

26. Dennis, R.A.; Maye, J.; Applegate, G.; Chokkalingam, U.; Colfer, C.J.P.; Kurniawan, I.; Lachowski, H.; Maus, P.; Permana, R.P.; Ruchiat, Y.; et al. Fire, people and pixels: Linking social science and remote sensing to understand underlying causes and impacts of fires in Indonesia. Hum. Ecol. 2005, 33, 465-504.

27. Chuvieco, E.; Cocero, D.; Riano, D.; Martin, P.; Martınez-Vega, J.; de-la-Riva, J.; Perez, F. Combining NDVI and surface temperature for the estimation of live fuel moisture content in forest fire danger rating. Remote Sens. Environ. 2004, 92, 322-331.

28. Gong, P.; Pu, R.; Li, Z.; Scarborough, J.; Clinton, N.; Levien, L.M. An integrated approach to wildland fire mapping of California, USA using NOAA/AVHRR data. Photogramm. Eng. Remote Sens. 2006, 72, 139-150.

29. Sukhinin, A.I.; French, N.H.F.; Kasischke, E.S.; Hewson, J.H.; Soja, A.J.; Csiszar, I.A.; Hyer, E.J.; Loboda, T.; Conrad, S.G.; Romasko, V.I.; et al. AVHRR-based mapping of fires in Russia: New products for fire management and carbon cycle studies. Remote Sens. Environ. 2004, 93, 546-564.

30. Tucker, C.J. Red and photographic infrared linear combinations for monitoring vegetation. Remote Sens. Environ. 1979, 8, 127-150.

31. Lyon, J.G.; Yuan, D.; Lunetta, R.S.; Elvidge, C.D. A change detection experiment using vegetation indices. Photogramm. Eng. Remote Sens. 1998, 64, 143-150.

32. Oldford, S.; Leblon, B.; Gallant, L.; Alexander, M.E. Mapping pre-fire forest conditions with NOAA-AVHRR images in northern Boreal forests. Geocarto Int. 2003, 18, 21-32.

33. Siegert, F.; Ruecker, G.; Hinrichs, A.; Hoffmann, A.A. Increased damage from fires in logged forests during droughts caused by El Nino. Nature 2001, 414, 437-440.

34. Schuck, A.; Brusselen, J.V.; Paivinen, R.; Hame, T.; Kennedy, P.; Folving, S. Compilation of a Calibrated European Forest Map Derived from NOAA-AVHRR Data; European Forest Institute: Joensuu, Finland, 2002; p. 44.

35. Chung, Y.S.; Kim, H.S. Satellite monitoring of forest fires and associated smoke plumes occuring in Korea. Air Qual. Atmos. Health 2008, 1, 111-118.

36. Crevoisier, C.; Shevliakova, E.; Gloor, M.; Wirth, C.; Pacala, S. Drivers of fire in the boreal forests: Data constrained design of a prognostic model of burned area for use in dynamic global vegetation models. J. Geophys. Res. 2007, 112, doi:10.1029/2006JD008372.

37. Xie, Y.; Sha, Z.; Yu, M. Remote sensing imagery in vegetation mapping: A review. J. Plant Ecol. 2008, 1, 9-23.

38. Li, Z.; Fraser, R.; Jin, J.; Abuelgasim, A.A.; Csiszar, I.; Gong, P.; Pu, R.; Hao, W. Evaluation of algorithms for fire detection and mapping across North America from satellite. J. Geophys. Res. 2003, 108, 4076. 
39. Joseph, S.; Murthy, M.; Thomas, A. The progress on remote sensing technology in identifying tropical forest degradation: A synthesis of the present knowledge and future perspectives. Environ. Earth Sci. 2011, 64, 731-741.

40. Franke, J.; Navratil, P.; Keuck, V.; Peterson, K.; Siegert, F. Monitoring fire and selective logging activities in tropical peat swamp forests. IEEE J. Sel. Top. Appl. Earth Observ. Remote Sens. 2012, $5,1811-1820$.

41. Eitel, J.U.; Vierling, L.A.; Litvak, M.E.; Long, D.S.; Schulthess, U.; Ager, A.A.; Krofcheck, D.J.; Stoscheck, L. Broadband, red-edge information from satellites improves early stress detection in a New Mexico conifer woodland. Remote Sens. Environ. 2011, 115, 3640-3646.

42. Schuster, C.; Förster, M.; Kleinschmit, B. Testing the red edge channel for improving land-use classifications based on high-resolution multi-spectral satellite data. Int. J. Remote Sens. 2012, 33, 5583-5599.

43. RapidEye AG. Satellite Imagery Product Specifications; RapidEye AG and RapidEye US LLC: Brandenburg an der Havel, Germany, 2012; p. 44.

44. Jia, G.J.; Burke, I.C.; Goetz, A.F.; Kaufmann, M.R.; Kindel, B.C. Assessing spatial patterns of forest fuel using AVIRIS data. Remote Sens. Environ. 2006, 102, 318-327.

45. Asner, G.P.; Jones, M.O.; Martin, R.E.; Knapp, D.E.; Hughes, R.F. Remote sensing of native and invasive species in Hawaiian forests. Remote Sens. of Environ. 2008, 112, 1912-1926.

46. Chuvieco, E. A Review of Remote Sensing Methods for the Study of Large Wildland Fires; Departamento de Geografía, Universidad de Alcalá: Alcalá de Henares, Spain, 1997; p. 192.

47. Kerr, J.T.; Ostrovsky, M. From space to species: Ecological applications for remote sensing. Trends Ecol. Evol. 2003, 18, 299-305.

48. Lentile, L.B.; Holden, Z.A.; Smith, A.M.S.; Falkowski, M.J.; Hudak, A.T.; Morgan, P.; Lewis, S.A.; Gessler, P.E.; Benson, N.C. Remote sensing techniques to assess active fire characteristics and post-fire effects. Int. J. Wildland Fire 2006, 15, 319-345.

49. Alencar, A.A.C.; Solorzano, L.A.; Nepstad, D.C. Modeling forest understory fires in an Eastern Amazonian Landscape. Ecol. Appl. 2004, 14, S139-S149.

50. Barrett, K.; Kasischke, E.S.; McGuire, A.D.; Turetsky, M.R.; Kane, E.S. Modeling fire severity in black spruce stands in the Alaskan boreal forest using spectral and non-spectral geospatial data. Remote Sens. Environ. 2010, 114, 1494-1503.

51. De Zea Bermudez, P.; Mendes, J.; Pereira, J.M.C.; Turkman, K.F.; Vasconcelos, M.J.P. Spatial and temporal extremes of wildfire sizes in Portugal (1984-2004). Int. J. Wildland Fire 2009, 18, 983-991.

52. Joseph, S.; Anitha, K.; Murthy, M. Forest fire in India: A review of the knowledge base. Jpn. For. Soc. Springer 2009, 14, 127-134.

53. Chuvieco, E.; Kasischke, E.S. Remote sensing information for fire management and fire effects assessment. J. Geophys. Res. 2007, 112, G01S90.

54. Giglio, L.; Descloitres, J.; Justice, C.O.; Kaufman, Y.J. An enhanced contextual fire detection algorithm for MODIS. Remote Sens. Environ. 2003, 87, 273-282.

55. Roberts, G.J.; Wooster, M.J. Fire detection and fire characterization over Africa using Meteosat SEVIRI. IEEE Trans. Geosci. Remote Sens. 2008, 46, 1200-1218. 
56. Wooster, M.J.; Zhukov, B.; Oertel, D. Fire radiative energy for quantitative study of biomass burning: Derivation from the BIRD experimental satellite and comparison to MODIS fire products. Remote Sens. Environ. 2003, 86, 83-107.

57. Achard, F.; Eva, H.D.; Mollicone, D.; Beuchle, R. The effect of climate anomalies and human ignition factor on wildfires in Russian boreal forests. Philos. Trans. R. Soc. B 2008, 363, 2329-2337.

58. Akther, M.S.; Hassan, Q.K. Remote sensing-based assessment of fire danger conditions over boreal forest. Sel. Top. Appl. Earth Observ. Remote Sens. IEEE J. 2011, 4, 992-999.

59. Pricope, N.G.; Binford, M.W. A spatio-temporal analysis of fire recurrence and extent for semi-arid savanna ecosystems in southern Africa using moderate-resolution satellite imagery. J. Environ. Manag. 2012, 100, 72-85.

60. Tansey, K.; Beston, J.; Hoscilo, A.; Page, S.E.; Hernandez, C.U.P. Relationship between MODIS fire hot spot count and burned area in a degraded tropical peat swamp forest in Central Kalimantan, Indonesia. J. Geophys. Res. 2008, 113, doi:10.1029/2008JD010717.

61. Morisette, J.T.; Giglio, L.; Csiszar, I.; Setzer, A.; Schroeder, W.; Morton, D.; Justice, C.O. Validation of MODIS active fire detection products derived from two algorithms. Earth Interact. 2005, 9, 1-25.

62. Giglio, L.; Randerson, J.T.; van der Werf, G.R.; Kasibhatla, P.S.; Collatz, G.J.; Morton, D.C.; DeFries, R.S. Assessing variability and long-term trends in burned area by merging multiple satellite fire products. Biogeosciences 2010, 7, 1171-1186.

63. Oertel, D.; Zhukov, B.; Thamm, H.-P.; Roehrig, J.; Orthmann, B. Space-borne high resolution fire remote sensing in Benin, West Africa. Int. J. Remote Sens. 2004, 25, 2209-2216.

64. Briess, K.; Lorenz, E. Systematic image processing of the small satellite mission BIRD. Available online: http://fred.unis.no/AGF218/Systematic\%20image\%20processing\%20of\%20BIRD\%20V2.pdf (accessed on 10 March 2014).

65. Falkowski, M.J.; Gessler, P.E.; Morgan, P.; Hudak, A.T.; Smith, A.M.S. Characterizing and mapping forest fire fuels using ASTER imagery and gradient modeling. For. Ecol. Manag. 2005, 217, 129-146.

66. Yamaguchi, Y.; Kahle, A.B.; Tsu, H.; Kawakami, T.; Pniel, M. Overview of advanced spaceborne thermal emission and reflection radiometer (ASTER). IEEE Trans. Geosci. Remote Sens. 1998, 36, 1062-1071.

67. Keramitsoglou, I.; Kontoes, C.; Sykioti, O.; Sifakis, N.; Xofis, P. Reliable, accurate and timely forest mapping for wildfire management using ASTER and Hyperion satellite imagery. For. Ecol. Manag. 2008, 255, 3556-3562.

68. Harris, S.; Veraverbeke, S.; Hook, S. Evaluating spectral indices for assessing fire severity in Chaparral ecosystems (Southern California) using MODIS/ASTER (MASTER) airborne simulator data. Remote Sens. 2011, 3, 2403-2419.

69. Hook, S.J.; Myers, J.J.; Thome, K.J.; Fitzgerald, M.; Kahle, A.B. The MODIS/ASTER airborne simulator (MASTER)-a new instrument for earth science studies. Remote Sens. Environ. 2001, 76, 93-102.

70. Mitri, G.; Gitas, I. Fire type mapping using object-based classification of Ikonos imagery. Int. J. Wildland Fire 2006, 15, 457-462. 
71. Bourgeau-Chavez, L.L.; Garwood, G.; Riordan, K.; Cella, B.; Alden, S.; Kwart, M.; Murphy, K. Assessing the potential for wildfire using ERS-2 SAR imagery. Alask. Satell. Facil. 2006, 3, 2.

72. Dobson, M.C.; Pierce, L.; Sarabandi, K.; Ulaby, F.T.; Sharik, T. Preliminary analysis of ERS-1 SAR for forest ecosystem studies. IEEE Trans. Geosci. Remote 1992, 30, 203-211.

73. Leblon, B.; Kasischke, E.; Alexander, M.; Doyle, M.; Abbott, M. Fire danger monitoring using ERS-1 SAR images in the case of northern Boreal forests. Nat. Hazards 2002, 27, 231-255.

74. Siegert, F.; Hoffmann, A.A. The 1998 forest fires in East Kalimantan (Indonesia): A quantitative evaluation using high resolution, multitemporal ERS-2 SAR images and NOAA-AVHRR hotspot data. Remote Sens. Environ. 2000, 72, 64-77.

75. Kasischke, E.S.; Bourgeau-Chavez, L.L.; Johnstone, J.F. Assessing spatial and temporal variations in surface soil moisture in fire-disturbed black spruce forests in Interior Alaska using spaceborne synthetic aperture radar imagery-Implications for post-fire tree recruitment. Remote Sens. Environ. 2007, 108, 42-58.

76. Andersen, H.-E.; McGaughey, R.J.; Reutebuch, S.E. Estimating forest canopy fuel parameters using LIDAR data. Remote Sens. Environ. 2005, 94, 441-449.

77. Mutlu, M.; Popescu, S.C.; Stripling, C.; Spencer, T. Mapping surface fuel models using lidar and multispectral data fusion for fire behavior. Remote Sens. Environ. 2008, 112, 274-285.

78. Mutlu, M.; Popescu, S.C.; Zhao, K. Sensitivity analysis of fire behavior modeling with LIDAR-derived surface fuel maps. For. Ecol. Manag. 2008, 256, 289-294.

79. Riano, D.; Meier, E.; Allgower, B.; Chuvieco, E.; Ustin, S.L. Modeling airborne laser scanning data for the spatial generation of critical forest parameters in fire behavior modeling. Remote Sens. Environ. 2003, 86, 177-186.

80. Riano, D.; Valladares, F.; Condes, S.; Chuvieco, E. Estimation of leaf area index and covered ground from airborne laser scanner (Lidar) in two contrasting forests. Agric. For. Meteorol. 2004, 124, 269-275.

81. Riano, D.; Chuvieco, E.; Ustin, S.L.; Salas, J.; Rodríguez-Perez, J.R.; Ribeiro, L.M.; Viegas, D.X.; Moreno, J.M.; Fernandez, H. Estimation of shrub height for fuel-type mapping combining airborne LiDAR and simultaneous color infrared ortho imaging. Int. J. Wildland Fire 2007, 16, 341-348.

82. Jubanski, J.; Ballhorn, U.; Kronseder, K.; Franke, J.; Siegert, F. Detection of large above-ground biomass variability in lowland forest ecosystems by airborne LiDAR. Biogeosciences 2013, 10, 3917-3930.

83. Blackbridge. Satellite Imagery Product Specifications; Blackbridge: Berlin, Germany, 2012; p. 47.

84. Irons, J.R.; Dwyer, J.L.; Barsi, J.A. The next landsat satellite: The landsat data continuity mission. Remote Sens. Environ. 2012, 122, 11-21.

85. Mouillot, F.; Schultz, M.G.; Yue, C.; Cadule, P.; Tansey, K.; Ciais, P.; Chuvieco, E. Ten years of global burned area products from spaceborne remote sensing-A review: Analysis of user needs and recommendations for future developments. Int. J. Appl. Earth Observ. Geoinf. 2014, 26, 64-79.

86. Thonicke, K.; Venevsky, S.; Sitch, S.; Cramer, W. The role of fire disturbance for global vegetation dynamics: Coupling fire into a dynamic global vegetation model. Glob. Ecol. Biogeogr. 2001, 10, 661-677. 
87. He, H.S.; Hao, Z.; Mladenoff, D.J.; Shao, G.; Hu, Y.; Chang, Y. Simulating forest ecosystem response to climate warming incorporating spatial effects in north-eastern China. J. Biogeogr. 2005, 32, 2043-2056.

88. Schumacher, S.; Bugmann, H. The relative importance of climatic effects, wildfires and management for future forest landscape dynamics in the Swiss Alps. Glob. Chang. Biol. 2006, 12, 1435-1450.

89. Schumacher, S.; Reineking, B.; Sibold, J.; Bugmann, H. Modeling the impact of climate and vegetation on fire regimes in mountain landscapes. Landsc. Ecol. 2006, 21, 539-554.

90. Sitch, S.; Huntingford, C.; Gedney, N.; Levy, P.E.; Lomas, M.; Piao, S.L.; Betts, R.; Ciais, P.; Cox, P.; Friedlingstein, P.; et al. Evaluation of the terrestrial carbon cycle, future plant geography and climate-carbon cycle feedbacks using five dynamic global vegetation models (DGVMs). Glob. Chang. Biol. 2008, 14, 2015-2039.

91. Battles, J.J.; Robards, T.; Das, A.; Waring, K.; Gilless, J.K.; Biging, G.; Schurr, F. Climate change impacts on forest growth and tree mortality: A data-driven modeling study in the mixedconifer forest of the Sierra Nevada, California. Clim. Chang. 2008, 87, S193-S213.

92. UNFCCC Secretariat. Compendium on Methods and Tools to Evaluate Impacts of, and Vulnerability and Adaptation to Climate Change; Final Draft Report; UNFCCC Secretariat: Bonn, Germany, 2008.

93. Sitch, S.; Smith, B.; Prentice, I.; Arneth, A.; Bondeau, A.; Cramer, W.; Kaplan, J.; Levis, S.; Lucht, W.; Sykes, M.; et al. Evaluation of ecosystem dynamics, plant geography and terrestrial carbon cycling in LPJ dynamic global vegetation model. Glob. Chang. Biol. 2003, 9, 161-185.

94. Henne, P.D.; Elkin, C.; Colombaroli, D.; Samartin, S.; Bugmann, H.; Heiri, O.; Tinner, W. Impacts of changing climate and land use on vegetation dynamics in a Mediterranean ecosystem: Insights from paleoecology and dynamic modeling. Landsc. Ecol. 2012, 1-15.

95. Thonicke, K.; Cramer, W. Long-term trends in vegetation dynamics and forest fires in Brandenburg (Germany) under a changing climate. Nat. Hazards 2006, 38, 283-300.

96. IPCC. IPCC Special Report. Emissions Scenarios. Summary for Policymakers; WMO, UNEP: Geneva, Switzerland, 2000; p. 20.

97. Finney, M.A.; McHugh, C.W.; Grenfell, I.C.; Riley, K.L.; Short, K.C. A simulation of probabilistic wildfire risk components for the continental United States. Stochast. Environ. Res. Risk Assess. 2011, 25, 973-1000.

98. Gebert, K.M.; Calkin, D.E.; Huggett, R.J.; Abt, K.L. Economic analysis of federal wildfire management programs. In The Economics of Forest Disturbances: Wildfires, Storms, and Invasive Species; Holmes, T.P., Prestemon, J.P., Abt, K.L., Eds.; Springer-Verlag: Dordrecht, The Netherlands, 2008; pp. 295-322.

99. Bachelet, D.; Lenihan, J.M.; Daly, C.; Neilson, R.P. Interactions between fire, grazing and climate change at Wind Cave National Park, SD. Ecol. Model. 2000, 134, 229-244.

100. Bachelet, D.; Neilson, R.P.; Lenihan, J.M.; Drapek, R.J. Climate change effects on vegetation distribution and carbon budget in the United States. Ecosystems 2001, 4, 164-185.

101. Rogers, B.M.; Neilson, R.P.; Drapek, R.; Lenihan, J.M.; Wells, J.R.; Bachelet, D.; Law, B.E. Impacts of climate change on fire regimes and carbon stocks of the U.S. Pacific Northwest. J. Geophys. Res. 2011, 116, G03037. 
102. Gonzalez, P.; Neilson, R.P.; Lenihan, J.M.; Drapek, R.J. Global patterns in vulnerability of ecosystems to vegetation shifts due to climate change. Glob. Ecol. Biogeogr. 2010, 19, 755-768.

103. Herrera, S.; Bedia, J.; Gutiérrez, J.M.; Fernández, J.; Moreno, J.M. On the projection of future fire danger conditions with various instantaneous/mean-daily data sources. Clim. Chang. 2013, 118, 827-840.

104. Williams, A.A.J.; Karoly, D.K.; Tapper, N. The sensitivity of Australian fire danger to climate change. Clim. Chang. 2001, 49, 171-191.

105. White, B.L.A.; White, L.A.S.; Ribeiro, G.T.; Fernandes, P.A.M. Development of a fire danger index for Eucalypt plantations in the northern coast of Bahia, Brazil. Floresta 2013, 43, 601-610.

106. Petros, G.; Antonis, M.; Marianthi, T. Development of an adapted empirical drought index to the Mediterranean conditions for use in forestry. Agric. For. Meteorol. 2011, 151, 241-250.

107. Flannigan, M.D.; Amiro, B.D.; Logan, K.A.; Stocks, B.J.; Wotton, B.M. Forest fires and climate change in the 21st century. Mitig. Adapt. Strateg. Glob. Chang. 2005, 11, 847-859.

108. Le Goff, H.; Flannigan, M.D.; Bergeron, Y. Potential changes in monthly fire risk in the eastern Canadian boreal forest under future climate change. Can. J. For. Res. 2009, 39, 2369-2380.

109. Nitschke, C.R.; Innes, J.L. Climatic change and fire potential in South-Central British Columbia, Canada. Glob. Chang. Biol. 2008, 14, 841-855.

110. Stocks, B.J.; Fosberg, M.A.; Lynham, T.J.; Mearns, L.; Wotton, B.M.; Yang, Q.; Jin, J.Z.; Lawrence, K.; Hartley, G.R.; Mason, J.A.; et al. Climate change and forest fire potential in Rusian and Canadian boreal forests. Clim. Chang. 1998, 38, 1-13.

111. Flannigan, M.D.; Stocks, B.J.; Wotton, B.M. Climate change and forest fires. Sci. Total Environ. 2000, 262, 221-229.

112. Carvalho, A.; Flannigan, M.D.; Logan, K.A.; Gowman, L.M.; Miranda, A.I.; Borrego, C. The impact of spatial resolution on area burned and fire occurrence projections in Portugal under climate change. Clim. Chang. 2010, 98, 177-197.

113. Fried, J.S.; Gilless, J.K.; Riley, W.J.; Moody, T.J.; de-Blas, C.S.; Hayhoe, K.; Moritz, M.; Stephens, S.; Torn, M. Predicting the effect of climate change on wildfire behavior and initial attack success. Clima. Chang. 2008, 87, S251-S264.

114. Groisman, P.Y.; Sherstyukov, B.G.; Razuvaev, V.N.; Knight, R.W.; Enloe, J.G.; Stroumentova, N.S.; Whitfield, P.H.; Førland, E.; Bauer, I.H.; Tuomenvirta, H.; et al. Potential forest fire danger over Northern Eurasia: Changes during the 20th century. Glob. Planet. Chang. 2007, 56, 371-386.

115. Herawati, H.; Santoso, H. Tropical forest susceptibility to and risk of fire under changing climate: A review of fire nature, policy and institutions in Indonesia. For. Policy Econ. 2011, 13, 227-233.

116. Lehsten, V.; Harmand, P.; Palumbo, I.; Arneth, A. Modelling burned area in Africa. Biogeosciences 2010, 7, 3199-3214.

117. Abatzoglou, J.T. Development of gridded surface meteorological data for ecological applications and modelling. Int. J. Climatol. 2013, 33, 121-131.

118. de-Groot, W.J.; Field, R.D.; Brady, M.A.; Roswintiarti, O.; Mohamad, M. Development of the Indonesian and Malaysian FireDanger Rating Systems. Mitig. Adapt. Strateg. Glob. Chang. 2006, $12,165-180$.

119. Martell, D.L.; Otukol, S.; Stocks, B.J. A logistic model for predicting daily people-caused forest fire occurrence in Ontario. Can. J. For. Res. 1987, 17, 394-401. 
120. Pew, K.L.; Larsen, C.P. GIS analysis of spatial and temporal patterns of human-caused wildfires in the temperate rain forest of Vancouver Island, Canada. For. Ecol. Manag. 2001, 140, 1-18.

121. Romero-Calcerrada, R.; Novillo, C.J.; Millington, J.D.A.; Gomez-Jimenez, I. GIS analysis of spatial patterns of human-caused wildfire ignition risk in the SW of Madrid (Central Spain). Landsc. Ecol. 2008, 23, 341-354.

122. Vega-Garcia, C.; Lee, B.S.; Woodard, P.M.; Titus, S.J. Applying neural network technology to human-caused wildfire occurrence prediction. AI Appl. 1996, 10, 9-18.

123. Chou, Y.H.; Minnich, R.A.; Chase, R.A. Mapping probability of fire occurrence in San Jacinto Mountains, California, USA. Environ. Manag. 1993, 17, 129-140.

124. De-la-Riva, J.; Perez-Cabello, F.; Lana-Renault, N.; Koutsias, N. Mapping wildfire occurrence at regional scale. Remote Sens. Environ. 2004, 92, 363-369.

125. Prestemon, J.P.; Pye, J.M.; Butry, D.T.; Holmes, T.P.; Mercer, D.E. Understanding broadscale wildfire risks in a human-dominated landscape. For. Sci. 2002, 48, 685-693.

126. Preisler, H.K.; Chen, S.C.; Fujioka, F.; Benoit, J.W.; Westerling, A.L. Wildland fire probabilities estimated from weather model-deduced monthly mean fire danger indices. Int. J. Wildland Fire 2008, 17, 305-316.

127. TNC; PROARCA/APM. Forest Fire Prediction in Mesoamerica Ecoregions. Mesoamerican Ecoregional Assessment; The Nature Conservancy: San Jose, Costa Rica, 2006; p. 23.

128. Westerling, A.L.; Bryant, B.P. Climate change and wildfire in California. Clim. Chang. 2008, 87, S231-S249.

129. Alonso-Betanzos, A.; Fontenla-Romero, O.; Guijarro-Berdinas, B.; Hernandez-Pereira, E.; Andrade, M.I.P.; Jimenez, E.; Soto, J.L.L.; Carballas, T. An intelligent system for forest fire risk prediction and fire fighting management in Galicia. Expert Syst. Appl. 2003, 25, 545-554.

130. Cortez, P.; Morais, A. A Data Mining Approach to Predict Forest Fires Using Meteorological Data. In Proceedings of The 13th Portuguese Conference on Articial Intelligence, Guimaraes, Portugal, 3-7 December 2007; pp. 512-523.

131. Dlamini, W.M. Application of Bayesian networks for fire risk mapping using GIS and remote sensing data. GeoJournal 2011, 76, 283-296.

132. Lozano, F.J.; Suárez-Seoane, S.; Kelly, M.; Luis, E. A multi-scale approach for modeling fire occurrence probability using satellite data and classification trees: A case study in a mountainous Mediterranean region. Remote Sens. Environ. 2008, 112, 708-719.

133. Maingi, J.K.; Henry, M.C. Factors influencing wildfire occurrence and distribution in eastern Kentucky, USA. Int. J. Wildland Fire 2007, 16, 23-33.

134. Stojanova, D.; Kobler, A.; Ogrinc, P.; Zenko, B.; Dzeroski, S. Estimating the risk of fire outbreaks in the natural environment. Data Min. Knowl. Discov. 2012, 24, 411-442.

135. McKenzie, D.; Peterson, D.L.; Agee, J.K. Fire frequency in the Interior Columbia River Basin: Building regional models from fire history data. Ecol. Appl. 2000, 10, 1497-1516.

136. Nepstad, D.; Lefebvre, P.; da-Silva, U.L.; Tomasella, J.; Schlesinger, P.; Solorzano, L.; Moutinho, P.; Ray, D.; Benito, J.G. Amazon drought and its implications for forest flammability and tree growth: A basin-wide analysis. Glob. Chang. Biol. 2004, 10, 704-717. 
137. Coen, J.L. Modeling Wildland Fires: A Description of the Coulped Atmosphere-Wildland Fire Environment Model (CAWFE); National Center for Atmospheric Research: Boulder, CO, USA, 2013; p. 38.

138. Coen, J.L.; Riggan, P.J., A landscape-scale wildland fire study using a coupled weather-wildland fire model and airborne remote sensing. In Proceedings of 3rd Fire Behavior and Fuels Conference, Spokane, WA, USA, 25-29 October 2010; The International Association of Wildland Fire: Birmingham, AL, USA, 2010.

139. Stratton, R.D. Guidance on Spatial Wildland Fire Analysis: Models, Tools, and Techniques. Report RMRS-GTR-183; Rocky Mountain Research Station, USFS, USDA: Fort Collins, CO, USA, 2006; p. 15.

140. Bradshaw, L.; McCormick, E. FireFamily Plus User's Guide, Version 2.0. ; U.S. Department of Agriculture, Forest Service, Rocky Mountain Research Station: Ogden, UT, USA, 2000.

141. Andrews, P.L. BehavePlus Fire Modeling System: Past, Present, and Future. In Proceedings of 7th Symposium on Fire and Forest Meteorology, Bar Harbor, ME, USA, 23-25 October 2007; American Meteorological Society: Bar Harbor, ME, USA, 2007; p. 13.

142. Andrews, P.L.; Bevins, C.D.; Seli, R.C. BehavePlus fire modeling system Version 3.0: User's Guide; Department of Agriculture, Forest Service, Rocky Mountain Research Station: Ogden, UT, USA, 2005; p. 134.

143. Finney, M.A. FARSITE: FireaArea Simulator-Model Development and Evaluation; Rocky Mountain Research Station: Fort Collins, CO, USA, 2004; p. 47.

144. Finney, M.A.; Grenfell, I.C.; McHugh, C.W.; Seli, R.C.; Trethewey, D.; Stratton, R.D.; Brittain, S. A Method for ensemble wildland fire simulation. Environ. Model. Assess. 2011, 16, 153-167.

145. Finney, M.A. An overview of FlamMap fire modeling capabilities. In Fuels Management-How to Measure Success: Conference Proceedings, Portland, OR, USA, 28-30 March 2006; Andrews, P.L., Butler, B.W., Eds.; Department of Agriculture, Forest Service, Rocky Mountain Research Station: Fort Collins, CO, USA, 2006; pp. 213-220.

(C) 2015 by the authors; licensee MDPI, Basel, Switzerland. This article is an open access article distributed under the terms and conditions of the Creative Commons Attribution license (http://creativecommons.org/licenses/by/4.0/). 